\title{
Manifest Dream/Association Comparison: A Criterion to Monitor the Psychotherapeutic Field (2nd part)
}

\section{Field Transformations: A Clinical Case}

\section{Patient Background}

I present the analysis, started at twenty-seven years of age, of a young man I will call Ermete (E.); he is in fact defined "hermetic" by his friends because of his closeness in communicating his emotional life (a closing done with Ermete's seal), as perfect as his parents want him to be. He himself sees his incapability of externalising feelings, because of a coldness he would like to change.

He contacts me because of an anxiety that prevents him from studying, causing him to be greatly behind in his medicine studies. He also notes the permanent and annoying presence of a herpes simplex on his lips and/or his nose since the first year of university. Associated with this, a year before the beginning of the analysis, he developed seborrhoeic dermatitis around his top lip and on his forehead near his hairline.

He is a young athletic and a good-looking man, who since his childhood, spurred by his parents, practised various sports with no passion. During the analysis, he finds "his" sport, to which, to his surprise, he dedicates himself with "perseverance", as in the cure, for all its duration. He defines himself as dedicated to "cheating" and as always having been "spoilt"; he leads his life as a game that he attributes to a "maturational hole".

His family is from a good social background. His mother lost both parents in her late adolescence, and before the conception of E., she had to go through two spontaneous abortions. His father, who works in health care, has difficulties walking because of a previous infection.

\footnotetext{
* This work is dedicated with profound gratitude to the memory of our friend and teacher Giuseppe Galli. The clinical case presented in this article and the conceptual framework for its analysis are the works of the main author Giancarlo Trombini; the evaluation of the Symptom Questionnaire (SQ) used in this case has been done by Anna Corazza; some remarks on the field concept in Gestalt psychology have been added by Gerhard Stemberger (in the first part of this article). The authors wish to express their gratitude to Dr. De Pascalis for the translation of the main part of the manuscript from Italian to English.
} 


\section{First Meeting}

E. arrives ten minutes late at our first meeting, because he "underestimated the distance from his house". He then discusses his substantial academic delay due to his incapacity to committing himself, a delay that, until about a year before, had remained unknown to his parents, who, after the beginning of his university studies, had already started calling him "doctor". His father had pressured him very much to start this course of studies, and he also expressed his preference for a particular future medical specialisation. Having discovered the son's academic situation, his father, fearing E. would become a "failure", is always in a bad mood. He wants him to be "competitive" and not passive as he was during his highschool studies. As a punishment, he takes away his beloved motorbike and the pocket money, which allowed him a wasteful life alternating friends, girls and motorbike races. He is a father who first gave all and then took all back. E. says: "He shouted at me and then thought that everything was alright. Instead things came crashing down again”.

Regarding our first meeting, an idea emerges in me that the patient arrived late as he had arrived late in his family. He came after two abortions and the prolonged depression of his mother who had to recover her desire to conceive. The analyst too then has to show his emotional availability, his desire to conceive him as a patient.

He tells me that the annoying skin conditions affecting his face are being cared for by an immunologist, but "without clear results". I am presented with the phantasy that the somatisations could be an attempt to build a casing of warmth. I feel a growing disposition to favour his autonomy, overcoming his "coldness" towards being in a couple. During the treatment, the patient says that his lateness at our first meeting could be seen as a way to test the analyst: whether he is able to wait or whether he stiffens up like his strict father who expects punctuality even though he never respects it. I also learn that his father, before convincing himself of the son's need for analysis, besides punishing him, had pushed for his passing examinations through recommendations to rather compliant professors. He is a father who is described as affectionate and available during E.'s childhood, as opposed to his mother. Although loving, she is presented as, at times, being indifferent. Sometimes, she also emerges as capable of severe crises of physical aggressiveness towards him. At the end of our first meeting, I have a clear impression that E. is a person with strong alexithymic traits. There is in him an operational thought, characterised by communications without emotion and imagination, which make him vulnerable to somatisation.

In my countertransference feeling, I soon sense sympathy for E., which will remain present in our analytic relationship. I believe this is linked to the affectionate relationship the patient had with his father in his childhood. 


\section{Initial Phase of the Analysis}

During the first month of treatment (with three weekly sessions), E. gives up on taking a university examination saying, "I'm not ready to take the exam and the herpes on my lip is tormenting me". He manages in the end to pass, but he complains about wasting time: "For the simplest of reasons I renounce studying. I can never stay still and I'm always chasing various projects that follow one another; from buying new bits to modify my motorbike to fixing various necessary things in the house for my parents".

The herpes continued reappearing in repeated and close flares. Facing the protracted lamenting about these symptoms, I found it useful to keep in mind, as in patients affected by somatisation, two pairs of attitudes: "relieving" and "inciting curiosity" and "clinical patience" and "wonder" (Trombini, 1994).

The patient gradually begins to understand how much the somatic ailments are linked to his emotions saying that "during the sessions we have always given it a motivation. The herpes symptoms were very painful when I decided not to take an exam because it was too hard or when daddy, who now insists I must not waste time, sold my motorbike". He therefore decides to stop the ineffective immunological therapies. Notwithstanding this, between other postponements, withdrawals and promotions, other examinations are passed. However, in these successes, on his own initiative, the father intervenes with various recommendations of the teachers.

\section{The First Dream}

After the first half of the first year, the somatisations became less painful and the first dream emerged in a session. E. says: "I am at the bus-stop near the hospital where we used to meet our lyceum friends. I wait for them, but unfortunately nobody arrives. The bus arrives, I get on, a black dog with a wolf-like muzzle gets on too. His fur is soft like those sled-pulling dogs. He stares at me like an owl. He is good, the people say. He has luminous eyes. Like a man he sits behind me. I fall asleep and, at the end of the trip, I return where I started. I must have slept for a long time then! When I wake up the dog is by my side: he has big eyes, almost smiling. He is not threatening. It is as if he is saying: give me, tell me something".

Analyst: "From behind to by your side".

E. "I had not noticed that he had passed from behind me to by my side. I think of my daddy who has always looked at me to tell me something or so that I give him something. My father has always stayed behind me then one day he came by my side. My dad is good in his own way, but he is difficult to understand. In the dream there will be the desire to solve the conflict with my father and then move on. He is not very 
elastic. I fear that, if I wanted to do something discordant, it could be a problem. There is in me the desire to have help from someone who stays behind you and then have him by my side, but I am not sure this happens with dad. Only if on my own I convince myself to pursue the specialisation he wants me to do, then he might be useful to me. But there are problems with his way of doing things which could complicate my life. I skimped on taking exams without telling him of my condition, because I hoped I'd manage on my own doing it my way. Like he had pushed me into choosing Medicine, he then did everything like he wanted regarding my exams, putting pressing on some teachers and suggesting some subterfuges to me that he would never have personally used".

\section{A.: "There is irritation".}

E.: "Because my father never asks me, he never wants to discuss things, he doesn't involve me. But of this he is not aware. In the end the fault is always entirely mine. It is true that I am not sincere and that I accept things, material or otherwise. It is my fault. But I am not free to choose like the other guys. I would like to manage myself, that way at least my father would not be in the way. Sometimes I even have the idea to make him pay for it, but I do not know how".

The criterion documents how the hope of being in a couple abandoning loneliness is regrettably hindered. The feelings tied to the vicissitudes with the father are blocking the possible progressive tendency that appeared for a moment.

Initially, in the dream, the patient is in the negative monadic position. He can no longer find the friends of his younger years. In the real world, he loves motorbikes, but in his dream, he chose a bus. The inside of a bus is a place where, together with strangers, one might have an "interpsychic experience lasting the time of a few stops" (Bolognini, 2016). There is a need for companionship, but in his condition of being behind with his studies, it is difficult to find any: he does not spend time with the university students. One could say that his high-school friends have left him as alone as a dog, but in his journey, a dog is actually there from start to finish: it stays by his side. It is now up to the analyst, lead sled dog, to take the patient's suggestion about how to develop a couple passing from behind to an accompanying stance for the duration of the treatment. It is necessary to stay side by side or "elbow to elbow", as indicated by Panizza (2006), to create the working $U_{s}$ in therapy, to create an intimate contact where the relationship becomes a place to find oneself and of transformation through a "partial nonconfusive fusionality" (Bolognini, 2016). In the narration of the dream, I was struck by the bus stop near the hospital and the long sleep during the journey. How long did it take him to realise that already in the high school he needed to be treated. For how long does he, who already feels so late, think that he will have 
to wait for the result of the treatment. In the associations, there is the desire to resolve his conflict with his father, to be able to develop a positive couple with him, but all this soon disappears and the patient finds himself in a negative monadic position of great anger. The relational dynamics therefore show signs of suffering, in which the patient compares an authoritarian and intrusive image of his father figure with the analytical one he feels close to him and driving him.

The manifest dream/association comparison (MDAC) criterion does not present a progressive dynamic, because the present suffering does not yet allow it, but it foreshadows the possibility of the constitution of a functional $U s$, a good sign for the therapeutic work.

During the next session, remembering the dream, E. says: "the wolfhound is aggressive and determined". He then adds, "when the round ends I will have an analyst by my side". A. says: "An internal companion after the analytical round". E. says: "That's right". He wants to find an analyst, who with determination stays at his side and is able to defend him from the authoritarian and intrusive father.

\section{Towards Graduation}

The patient resumes taking examinations, withdrawing from some to then succeed in them. Sometimes his father still pushes recommending him, but E. strengthens his decision to make it by himself. He comments: "Making it by oneself is really better". He also asks himself "whether parents are enemies or useless". Having to resist an objectively difficult examination, made worse by the notoriously rather sadistic behaviour of the specific teacher, he feels well prepared because he has changed his study method and no longer has the attitude of just going around an obstacle. E. says: "I would like to pass the exam for my parents but they would be happy even if I explained to them this new attitude of mine. I have done a good job with you!". The herpes on his lip and nose has not appeared as it always did before an examination. About the lip, I have a fantasy that he managed to distance himself from his old attitude, while about the nose, he does not smell something could go awry with the examination: he feels ready. Now the patient shifts the accent of his value from graduating to the degree of autonomy conquered.

Finally, after a year and a half, he passes the last examination. The next day, going on a bicycle "like a crazy man" down a steep hill, which he already knew well, he has a ruinous fall with painful prolonged consequences. He comments, "It's the punishment for the subterfuges I used during my studies".

He was now a prey of the intense fear that, at the moment of graduation, these subterfuges would come to light, denying him the achievement. I think that in 
addition to the desire to graduate, there is also the fear that the period of adolescence will conclude and that he will have to face maturity and choose what to do after graduation. He in fact yearns to not use his degree but to dedicate himself to activities like being a mechanic for racing cars or car salesman.

He has a dream in which he sleeps with others, among which is his girlfriend, in the home of a snobbish friend of his. This friend, who in reality had seen him come for analysis, suddenly shines a light on him and exposes a preliminary move of his to have sex with his girlfriend. He comments: "She saw me in an intimate situation like coming here". In the oneiric narration, he is in a negative dyadic situation with the friend. In the associations he says that his parents find him better and they would be shocked if they suddenly found out, like in the dream, his faults and an impediment to his graduating. E. says: "I torture myself when I enter the university, I feel a sense of guilt, of fear. I feel discouraged and even angry. In the next few days, I must finish my thesis. Will I make it or will they find me out? If I weren't on this analytical journey I would never understand that the bad things I did were a neurotic act because I could not see other solutions".

In the association, the patient, although feeling a good therapeutic alliance, puts himself in a negative monadic position coloured by an emotional state alternating between various feelings. The friend in the dream can represent that narcissistic aspect of his that goes against the analytical coupling (the coming here). During the session therefore, there are no signs of a dynamical progression. In a subsequent session, he was asked to complete a self-report measure on his emotional state to clarify some aspects of it and, above all, value its intensity.

\section{The Request for a Self-Report Measurement}

The patient, who has already expressed feeling prey to various emotions, such as fear, discouragement, feelings of guilt and anger, laments feeling confused. He would therefore like to have more clarity on the quality and intensity of the feeling presently emerging to his consciousness: to know for example if it is anxiety, depression or anger that dominates his emotional stage. I therefore wonder if one can associate what emerges in the analytical dialogue to the result of a psychometric test, known to him through his university studies, to evaluate the quality and intensity of the present complex emotional state and about which we could thus further speak. The test is a self-report symptomatology questionnaire: the Symptom Questionnaire (SQ) by Kellner (1987). The questionnaire, brief and simple, contains four scales: anxiety, depression, somatic symptoms and hostility. If the score of the scale is 1 standard deviation (sd) above the relative average for normal subjects, there is moderate distress, while a score above 2 sd suggests the presence of severe distress. The SQ is particularly used for test-retest. 
In clinical practice, this self-evaluation questionnaire is used as an objective test that gives voice to conscious aspects of the person's self and of the relationship with the other.

I ask myself whether to adopt an interpretative line or whether to agree to his request. I choose the latter because accepting his request seems like the most useful modality of supporting the patient in his need to have an objective element reassuring him on the actual presence and intensity of particular feelings of his. The SQ can become another occasion for dialogue inserting itself in the session narrative. It is a dialogical opportunity allowing one to develop together considerations about the feelings that emerge in his consciousness. I think that the various answers to the items become communications to the analyst, which the patient might want to express and make known. The result of the test therefore does not configure itself as a merely "objective" information that the patient can consider distinct from the analytic dialogue. I feel that the diffidence towards his analyst does not prevail in E. but rather an expansion of our communication.

E., from now on, will be able to complete the SQ before the beginning of the session while he is waiting, every time he wants to. This way the analyst will observe when, how and why the measure is completed. There will also be the opportunity to compare the contents of the SQ answers and the trend of the MDAC data evaluating thus their possible convergence.

Table 1 shows the results of the SQ obtained during various months (indicated by their number) from the second to the fourth year of analysis. The standard deviation ( $\mathrm{sd}$ ) values are given for the anxiety, depression, somatic symptoms and hostility scales. A score higher than 1 sd indicates distress, while anything higher than 2 sd indicates severe distress.

\section{Waiting for Graduation}

During the week following the fall from the bicycle, in the seventh month of the second year of analysis, E. completes his first SQ. The results reveal an intense depression, and a moderate anxiety and hostility. He comments that he needs to change his conduct and that, if he were not in analysis, such conduct would continue. He adds: "I must learn to manage the anxiety attacks both my father's and mine".

Further on he dreams: "I steal a bus, I drive it and nobody realises. I make a mistake in the bus route and I find a bend in the road. I make a mistake in the manoeuvre, so I leave the bus at the cross-roads and get off. Then I go into a house where they do not bother me". He comments: "I stole during my studies. My father's recommendations to my teachers, a help I did not refuse, and my subterfuges not to have to study for the exams, are a theft. My fall on the bicycle is a 


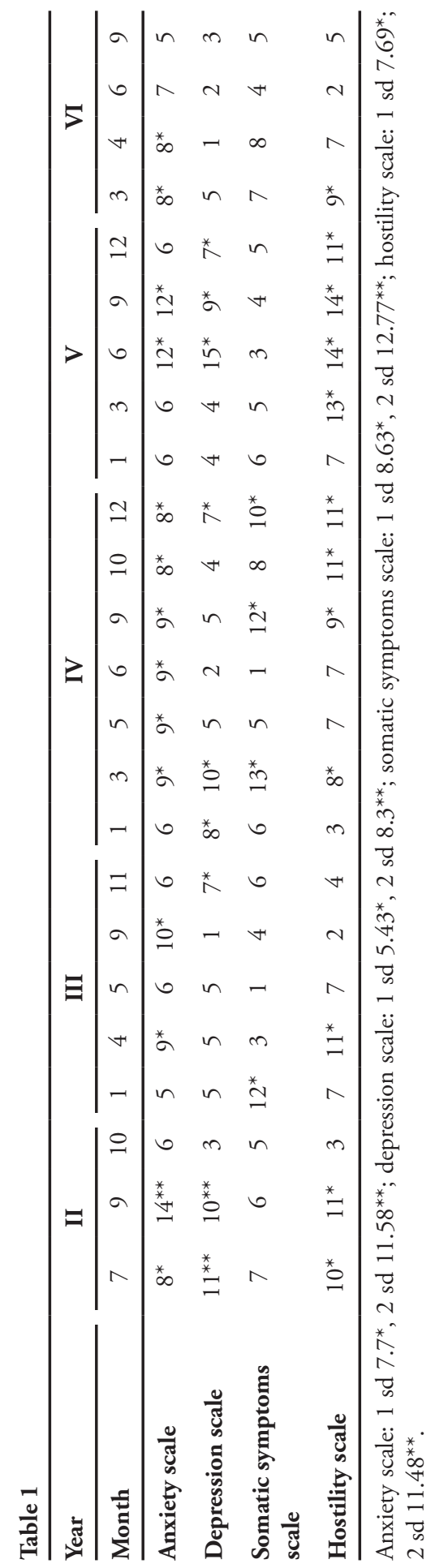


way of punishing myself for the lies, and for the university choice I made without much reflection. I let myself be pushed. The fall is also a way of seeking help for myself who keeps everything to himself. I have parents who do not pay attention. It is difficult to make them understand something other than the act itself. Even when I was a child I was a handful and I invented lies. They didn't always believe my truth. They gave me punishments that left me with such an anxiety I couldn't explain myself".

The patient during the oneiric narration (again inside a bus) is in a negative monadic negative position. He does not know which road to take (he leaves the bus at the crossroad) now that the graduation is imminent. In the dream, E., although in a bus with passengers, finds himself alone because nobody notices (talking to the driver is forbidden). It is then he who leaves the collectivity to be alone in a house where nobody bothers him (monadic position he considers positive). In the associations, he criticises himself and presents a negative triadic relationship with his parents whom he feels do not understand him. They only consider the worth of the achieved degree and do not understand how much sense of guilt E. carries within himself and the anguish he has having to face the new road ahead of him: the specialisation strongly suggested by the father, thanks to which the son would then remain quite close to him. The relational dynamics, shown by the MDAC, is always critical. I am comforted by the thought that the "house where they do not bother me" in the dream might represent the analytic house, where nobody is bothered. During this session, the SQ shows us an emotional state converging with what emerges from the MDAC: the results of the test in fact show severe anxiety and depression but moderate hostility.

\section{Towards Professional Habilitation}

After graduating E. comments; "The melancholy I feel is strange. I miss those eight university years, but I don't even have a complete medical preparation. I expected a great herpes the day after graduating, instead there was a tiny bit on my lip. I have waited in terror of being discovered, but now it is over". He has calmed down, and the results of the SQ as well exclude a state of discomfort, that is they are in a normal range (October - second year).

To make up for his medical shortcomings, he starts attending with satisfaction the office of a GP and the A\&E department. The examination for professional habilitation draws closer, and unfortunately, the studying difficulties return. A stiff neck appears like it used to do during his university course when having to face, particularly, difficult examinations. The SQ (January - third year) shows distress for the somatic symptoms scale. E. says: "I dream of a girl who accompanies me and then disappears (negative dyadic position). On awakening I discover I have wet the bed. I suffer from the approaching change: becoming a worker". 
The associations evidence a negative monadic position. The patient now somatises a passage from skin disorders to muscular pain and urinary incontinence. Holding back change brings him pain. Is being left alone in the dream by the girl a fear of being abandoned by the analysis, which has accompanied him until now? Psychoanalysis could in fact abandon him and put an end to the accompaniment, as expected by his father, who considers the treatment concluded as he cannot see his son's emotions. There is a difficulty in containing (the incontinence) anxiety and anger towards his father who expects a conclusion and also towards the analyst because $\mathrm{E}$. fears that he might agree to his father's requests. The patient feels painfully blocked, not knowing which way to turn his head (the stiff neck). That which the other does not mentalise, the emotion the other does not see is reassumed in the patient. What the other does not mentalise, the emotion that the other does not look at is somatised in the patient.

The MDAC criterion shows a crisis in the relational dynamics. Before the examination, some aphthae appear in his mouth: there are gaps and difficulties in speaking. "I managed by myself without counting on dad", he will say after getting the habilitation, adding "Although tiny, it is a nail I managed to hammer", a strengthening of his autonomy value.

\section{Searching for a Specialisation}

The patient is waiting for the specialisation post forcefully suggested by his father to be advertised. E. says: "There is always my dad's shadow behind my choice". He fears trapping himself like he did when he started Medicine. The father pushes him to take a self-financed post at a clinical institute where he knows the director. E. tries to oppose the idea, which leads to a fight, but notwithstanding this, he begins occasionally attending. The aphthae reappear, so the patient hypothesises: "With dad I must keep my mouth shut!". The patient is starting to give psychic meaning to his physical symptoms. He dreams being imprisoned in jail. He does not want to be tied down to a specialisation only his father is convinced of. $\mathrm{He}$ counters the negative relational dynamics with the parent and with his relationship with the analyst. E. says: "Thank goodness that on my way back from the institute I come to the analysis". At the same time, the SQ (April - third year) indicates distress in the anxiety and hostility scale.

The specialisation post is advertised. He dreams of pushing two shopping trolleys in which he has divided his groceries so as not to make them too heavy and he feels well (positive monadic position). E. says: "My father has become less heavy since my graduation. Our communication has clearly improved. I am more and more cutting the umbilical cord which I have more with him than with mum. Moreover a GP has asked, for some days of the week, my collaboration". In the dream, it is now him who carries all the shopping. Associations 
follow with two positive dyadic relationships. Even the results of the SQ seem normal (May - third year). The experience with the GP is satisfactory, but regarding the specialisation entry examination, he fears "embarrassing himself" because he "rarely looks at" the study books. He dreams of a man with a perforated eye: he is blinded in a negative monadic position. He then speaks of a dinner with his father who is far away from him "tired and pensive holding his head in his hands" (negative dyadic relationship). Even in the SQ, there is anxiety (September - third year).

\section{After Failing the Specialisation Examination}

He fails in the examination and that is the beginning of two, rather troubled, years in the search of his own road. Now, with the MDAC criterion, in many sessions dedicated to medical work, family and shenanigans with his friends, negative monadic and dyadic states appear both in his dreams and in the respective associations: the relational dynamics are profoundly critical.

Episodes of life with his mother emerge. These depict a person very careful in attending to her son's physical development through sport activities like swimming, which he rather dislikes (although successfully performed during competitions) and then abandons at the beginning of high school. E. comments on the many episodes of her emotional distance as consequence of a depressive state (she had not been able to dedicate herself to her passions such as music because of her educational commitments) or of deep marital conflicts brought about by jealousy. He remembers a childhood episode in which, walking up a hill, his mum did not realise that as a child walking behind her he could not keep up. So E. silently went back towards home risking a severe accident.

It is a maternal image frequently seen in the life of those who somatise and E. soon somatised the containment inabilities with his holding back his faeces during the school period. The young E. then sought comfort in the father who in that phase proved close and affectionate.

During those two difficult years of analysis, in which he later said that he had thought of interrupting it, he tried to bring to light the analyst's paternal side, not standing being able to think of me as the distant mother, now disappointed by his ways of life.

E. in fact during these two years alternates getting drunk with his friends, occasional contacts with other girls and the fear he is at the end of the line with his own. Notwithstanding this, he works with continuity and seriousness in the substitution of GPs and in out-of-hour clinics. The relationship with the patients when he is working as an out-of-hour doctor is often an occasion for profound irritation with the patients. During the night, he feels obliged to visit them for 
requests that, according to him, are baseless. The dermatitis around his mouth intensifies. From his description of it, I tell him that he makes me think of a dog's muzzle. During the next session, he informs me that the dermatitis causes him a strong burning sensation. E. says: "Maybe it is to stop me protesting with the patients who wake me up for nothing!" He sometimes indulges in making silent telephone calls to his patients to disturb them. I think that even with me he is mute since he has begun arriving very late to the last few sessions, an unusual event. He wants to maintain a good relationship with his therapist, and with his absence, he does not allow himself to give voice to complaints regarding the analysis, which he feels stalled, causing me irritation.

During this period, E. goes rather frequently to the clinical institute, because he still hopes to specialise, even though he still manifests uncertainties about which professional course he should choose. A talk with the director then makes him lose hope about being able to start his specialisation course. At the same time, herpetic symptoms reappear on his nose. He now starts preparing papers to achieve professional habilitation abroad, exploring at the same time the possibility of finding a place in another Italian polyclinic. He laments feeling inhibited in applying himself to the studies of both Medicine and a foreign language: he only does well in practical activities.

The distress results in the various SQs (from November - third year to December fifth year) show a phase of oscillation between anxiety, depression, somatisations and hostility. About this E. comments: "I want to see if the data correspond to what I am feeling. Sometimes I do not understand all the anger resulting from it. I don't know if I still have the depression of some time ago". The bidirectional exchange between patient and analyst in a particular episode is also reported. The adjectives of the various SQ items, such as "irritable", "afraid" and "calm", are qualities that subjects completing the measure must attribute to themselves. After a few SQs, I find out that the patient interprets the "despicable" item as to attribute to others, without being aware of his error. It is only through the dialogue with the analyst that the patient recognises that it is himself he considers despicable (projection). This also becomes the acknowledgement, on the analyst's part, of the inner work done by the patient.

The analytic process meets various discouragements, but the therapeutic alliance manages to remain trustful. E. comments: "I am afraid to get stuck but time after time, we will see and manage the situation. Coming to the session I am half way between an impulsive behaviour and a reflexive one. My skin has greatly improved. It is because we have worked on it in analysis". He considers the herpetic manifestation on his lips an expression of an "emotional state of separation", and for those of the nose he says: "They come when I smell that something is wrong". At the time of the Christmas separation of the fifth year in analysis, he tells me: 
"In the last two years I have changed my relationships with people. With also the support of my girlfriend I have started celebrating Christmas again, which I'd stopped doing at sixteen. It's impossible, for the lump I feel in my throat, to tell my dad that I thank him for spending time with me accompanying me for the motorbike race on the track". In occasion of our Christmas separation, the turmoil of emotions makes him cry: during the long time spent together, his emotional coldness has melted away. He is capable of allowing himself enjoyable but also painful moments (development of explicitly ascertainable analytic functions, in the sense of Bolognini, 2008).

\section{The Deer Dream}

I shall now describe a session (January - fifth year) in which E. begins, as he often did, complaining that he "does too many things" and that he cannot study. I feel emerge in me a negative emotional reaction thinking this to be the usual complaint he might follow with a description of his drinking and womanising. The patient however immediately tells me of a dream in which this time after the many negative dreams of the prior years, a positive aspect of the Self appears. My inner attitude changes, and I listen impassioned.

E. says: "I see the head of a deer which is going around in a lake but cannot get out. The water is muddy with snakes and insects. Even though I have a phobia for them I jump in to look for it. The water is turbid and I can't see anything, but going deeper it is completely limpid, I can see clearly: there are dead snakes and adders on the bottom, but the deer is not there". He comments: "going to the bottom searching one sees clearly in the session. The problems seen here together are dead, they don't frighten me". He senses associative links (development of analytic functions, in the sense of Bolognini, 2008). Then he adds that deer "if they are scared run away without thinking". He is the deer. About himself he says: "If I am not accepted at the Polytechnic, it is better to calm down, stop anxiously searching and go ahead with the analysis and with the medical work I am doing. I am frightened the passing of time, my age is affecting me, but we see, we swim!" He remembers when he went swimming in the pool with his mother, and for the first time, he tells me that usually after the boring sport activity, he very happily went to the cinema with her. Then he shows me a photograph of his girlfriend saying that she is "a valid person" and that he finds himself well with her.

In the dream he immediately shows his courage (positive monadic position). In the associations, he speaks about moments of enjoyable sharing with his mother, along a path where only negative aspects had previously emerged. Two other positive couples appear: with analyst and with his girlfriend. These are maturational dynamics with a clear reference to work in couple. 
During the session, the MDAC criterion signals a positive beginning in the dream. This gives me confidence in seeing what is happening through another narrative frame, a new reference system, and stimulates me to regain vitality in my contact with the patient. My attitude is founded in the contrast between my mental state at the beginning of the session and the emotions that later emerge when the criterion shines a light on a new vision. The criterion has therefore favoured the renewed rise of the interest of the therapist who becomes passionate about the narration and the comment of E. Passion is a fundamental presence in the psychoanalytic setting (Bion, 1963).

The SQ data as well (January - fifth year) are normal.

He now intensifies his frequentation of the polyclinic he had already contacted. He finds it difficult to study and does not pass the various examinations he has to face. During the following sessions, he expresses strong irritation, even in the SQ (March - fifth year), for having wasted time and money. He regrets the "holes" in his medical preparation (the aphthae reappear). Once again the father steps in, without asking his son, to recommend him at the polyclinic. E. dreams someone has stolen his motorbike and comments: "It is the theft of free choice". He remembers sad aspects of his childhood with his parents. He passes therefore from the negative monadic position to the negative triadic position. With the SQ (June - fifth year) he gives signs of severe anxiety, depression and hostility. In the following ones as well (September and December), there is malaise, until the patient says he told his father: "Now I can see something positive in being an out-of-hour doctor. It is as if I had done military service; it would have been a good thing. As long as it doesn't last too long!". He adds: "I feel a bit better. Even the herpes has stopped returning. After the blow of the failed specialisation exam I am reorganising myself: I am now convinced I shall go for the specialisation suggested by my father. It is difficult to enter the Polyclinic. I am getting ready to go abroad". This initiative finds the favour of the father who in the past had refused separation between himself and his son: their relationship is changing.

\section{Going Broad}

Notwithstanding there being resistance, E. for the first time hears an inner voice saying: "Go!". He sends his curriculum to the head teacher of the specialisation institute. If accepted, he will be assessed to have access as a "frequenter". E. says: "The problem is that I don't study, I sent my request". He also worries about the future of the analysis: he hopes to be able to continue switching to one session per week.

The anxiety of waiting turns to irritation (SQ; March - sixth year), when he is not accepted. However, during a later telephone contact, the director gives him 
an appointment. He is waiting for the go with deep anxiety that the patient also feels consciously (SQ; April - sixth year). E. in session wonders whether in this phase, the analysis "is not doing much".

To answer his question, I think I have to go back to what has recently emerged with the MDAC criterion. In the dialogue with E., I thus return to our last two sessions. In the first session, the patient had dreamt of hitting a man assigned to vehicle removal who was taking away his motorbike (negative couple) while he was in a café. Analyst says: "You wanted to stay there in the calm in the café in peace with your friends having fun and trouble to whoever caused you to leave, but then you commented that it is a good thing to leave your city, your parents and go abroad and that you will speak to your father to see what he thinks about it (positive couple)". In the second session, he dreamt he was at the city's polyclinic with his friends and one of them bashed in the bank cash machine. E. too started picking up the banknotes, but he thought it was "a theft" and stopped it there (positive monadic position). Analyst says: "You did not associate yourself with that theft, you have already committed an information theft by boasting about more competence (credits) in the curriculum for the professor. Now no more on this road. Then in the associations you coupled with your father in organising a stay abroad. That has been an evolution”.

Patient: "I had not thought about it from that point of view. It seemed to me that the analysis was a bit stuck".

Analyst: "Could you be devaluating it so as to suffer less if you must abandon it?"

E.: "I always do that: with girls if they left me I devaluated them".

He tells me that "he had enjoyed" his meeting with the head teacher, who "is direct, calm, simple and speaks clearly”. He is taken on for a 2-month probation period and later obtains a 1-year contract as an assistant.

During this clinical work, he says: "He's an incredible professor! He knows one needs time to learn. When I can't manage I tell him. I don't hide it as I did before. It is an enormous change! I am doing the specialist work that I have always fought within myself. Even the dermatitis on my face has gone (he can speak, he no longer fears biting! The muzzle is also a mask which is no longer of use!)". The SQ (June - sixth year) that E. brings to the session shows results in the normal range.

Now he has one weekly session. Being near to the summer holidays, we think about concluding the analysis at the end of the year, also because of the difficulties brought about by the journeys abroad.

"It is an important separation, I will miss the sessions", says the patient. The same stands true for myself, I think. 


\section{Separation}

When the analysis resumes, E. dreams: "I am walking along the motorway. Near me, in the overtaking lane there is a wolfhound, but he is good. I tell him to move because someone might arrive. He moves behind me and he follows me. To this he associates: "The dog might be you". I comment: "We no longer need to be side by side". E. says: "Some time ago, I who love dogs very much, saw a wolfhound in the other lane of the motorway. I love them because they represent the couple, friendship and loyalty, they are my alter ego. I reached the tollgate then I went back to get him. I run after him but he dropped the bone he had in his mouth, he dashed down a slope and I lost sight of him".

Suddenly I feel that the time of the analysis is at its end and that I must drop him. A few hours later, I discover that on my bottom lip there are signs of herpes, which I have not had for a long time. The analyst has joined E. even in his body, living his mental contents even sensorially on his own skin (De Toffoli, 2014; Solano, 2013), especially in the oral zone, which E. had linked to separation. I think that the patient does not sense the sudden emotion for the separation that I now feel: even the unseen pain of the analyst finds expression in the body.

The patient concludes telling me that he is enjoying working at his professor's side in his professional activity. Progressive relational dynamics developed in session are positively noted. His first dream returns to my mind. E. has now found somebody to accompany him in his specialisation journey.

\section{Conclusions}

In the present paper, we followed the transformations of the psychotherapeutic field through the relational dynamics that occur within it. It was shown how the "manifest dream/associations comparison" criterion can monitor the relational progress of an analysis lasting six years.

The patient was not able to complete his studies in Medicine, and he was tormented by annoying physical symptoms affecting his face.

The meaning of the first dream, which appeared during the seventh month of treatment, is to suggest how the patient wants to be followed in therapy: side by side with analyst, felt as close to him and driving him. The latter is compared to the authoritarian and strongly intrusive father figure. With his father, the son is in a conflict he is not able to resolve. The relational dynamics in fact show signs of suffering to the criterion. These signs last for a long time because the patient is tormented by a sense of guilt for his immature and reprehensible behaviour during his university studies.

His family only considers the worthiness of the degree when he graduates. They do not understand the malaise of their son, scared of being trapped in the 
specialisation strongly wanted by his father with the aim of keeping him close to himself.

The analytical journey encounters various discouragements, but the therapeutic alliance remains trustful. The patient manages to lose the image he has of himself as one who steals; he strengthens his value of autonomy and understands that more than the graduation, his merit is the maturity he has reached.

He manages to give a psychic meaning to the symptoms affecting his face, which become rarer and rarer until they disappear.

His coldness with his father melts away.

With a dream (of a deer), he shows he can find his own way valourising the working US formed by the analyst-patient couple. The criterion is also used to communicate with the patient and support him even when he autonomously decides to move abroad for his specialisation. Finally, his father approves of him.

In the last dream, maturational to the criterion, the separation becomes alive and it is the analyst who feels the patient's psychic contents on his own skin.

In essence, using the criterion shows us that what is observed are not isolated photograms, but if linked, they express their dynamic intertwinement that gives evidence to the transformations of the psychotherapeutic field.

The (accidental) possibility of observing self-report data during the course of the analysis also presented itself. It is a psychometric test requested by the patient (and not suggested by the analyst) that during the treatment transformed itself from being a monadic instrument to being a means for a bidirectional exchange. The data obtained show a complete convergence with what emerges from the suggested criterion.

\section{Summary}

The present work focuses on the transformations of the psychotherapeutic field through the relationship dynamics that occur within it.

The first part of this article starts with a brief outline of the Gestalt psychological understanding of the field concept, also in its application to the psychotherapeutic situation, followed by a brief review of the introduction of the field concept into the psychoanalytic theory formation.

After this, the first author first presents the theoretical concept underlying a new approach he has developed for observing the relationship dynamics in psychotherapy. Mirroring a formation both psychoanalytic and gestaltic of the main author, this new approach is based on the combination of psychoanalytic and Gestalt psychological concepts. According to the clinical experience and insights of the author, the phenomenological and relational approach of Gestalt theory fits well with the psychoanalytic approach; on this basis, a criterion for recording the progress of therapy can be developed. This criterion is the phenomenology of the development of the qualities of the relationships of the 
client, as they become visible in his dream narrations and the subsequent associations in the analysis room, and continue to develop during the session and the further course of therapy. The relationship dynamics in the dream narration is thus compared with those that develop in the course of the subsequent associations.

This is demonstrated and further elaborated in the second part of this paper on the basis of a clinical case. The clinical example shows how the relationship dynamics develop in this sense in the individual therapy sessions and over a longer course of therapy. The associated transformations of the therapeutic field give a good indication of the progress of therapy. The main author gained such insights into the transformations of the therapeutic field and the progression of therapy, which are visible in the course of therapy, from the careful application of the criterion "manifest dream/associations comparison of relational dynamics". In the specific case, there was also a high degree of correspondence between the results of the application of this phenomenological criterion and the empirical evidence of the symptom questionnaire, a self-report measure requested by the patient himself during the course of the therapy.

Keywords: Psychotherapeutic field, psychoanalysis, Gestalt psychology, relational dynamics, dream, free association, therapy progress.

\section{Der Vergleich zwischen manifestem Traum und Assoziation: Ein Kriterium zur Erfassung der Entwicklung des psychotherapeutischen Feldes}

\section{Zusammenfassung}

Die vorliegende Arbeit beschäftigt sich mit den Transformationen des psychotherapeutischen Feldes durch die Beziehungsdynamiken, die in ihm auftreten.

Eingangs wird das gestaltpsychologische Verständnis des Feldkonzepts dargelegt, auch in seiner Anwendung auf die psychotherapeutische Situation, gefolgt von einem kurzen Rückblick auf die Einführung des Feldkonzepts in die psychoanalytische Theoriebildung. Im Hauptteil des Artikels stellt der Erstverfasser zuerst das theoretische Konzept vor, das einen von ihm für die Beobachtung der Beziehungsdynamik in der Psychotherapie entwickelten neuen Ansatz zugrunde liegt. Dieser Ansatz beruht - dem Werdegang des Autors entsprechend - auf der Verbindung psychoanalytischer und gestaltpsychologischer Konzepte. Der phänomenologische und relationale Ansatz der Gestalttheorie lässt sich gut mit dem psychoanalytischen Ansatz integrieren; auf dieser Grundlage lässt sich ein Kriterium für die Erfassung des Therapiefortschritts entwickeln. Dieses Kriterium ist die Phänomenologie der Entwicklung der Beziehungsqualitäten des Klienten, wie sie in dessen Traumberichten und den nachfolgenden Assoziationen dazu in der Therapie sichtbar werden und sich weiter entfalten. Die Beziehungsdynamik in der Traumerzählung wird also mit jener verglichen, die sich im Zuge der anschließenden Assoziationen entwickelt. Dies wird dann im zweiten Teil dieses Beitrags anhand eines klinischen Falls demonstriert und näher ausgeführt. Das klinische Beispiel zeigt, wie sich die Beziehungsdynamik in diesem Sinn in den einzelnen Therapiestunden und über einen längeren Therapieverlauf entwickelt. Die damit verbundenen Transformationen des therapeutischen Feldes geben einen guten Hinweis auf den Therapiefortschritt. 
Solche Aufschlüsse über die im Therapieverlauf sichtbar auftretenden Transformationen des therapeutischen Feldes und über den Therapiefortschritt gewann der Hauptautor aus der sorgfältigen Anwendung des Kriteriums „Vergleich der Beziehungsdynamiken im Traumbericht und den anschließenden Assoziationen“. Im konkreten Fall zeigte sich auch eine hohe Übereinstimmung zwischen den Ergebnissen, die die Anwendung dieses phänomenologischen Kriteriums erbrachte, mit der empirischen Evidenz des SymptomFragebogens, dessen Einsatz begleitend zur Therapie der Klient selbst gewünscht hatte.

Schlüsselwörter: Psychotherapeutisches Feld, Psychoanalyse, Gestaltpsychologie, Beziehungsdynamik, Traum, freie Assoziation, Therapiefortschritt.

\section{References}

(for part one and two of this article)

Albarella, C. (2004). L'isteria: intervista a Christopher Bollas. In C. Albarella \& A. Racalbuto (a cura di), Isteria (pp. 207-220). Roma: Borla.

Baranger, M., \& Baranger, W. (1961/2 in 2008). The analytic situation as a dynamic field. The International Journal of Psychoanalysis, 89, 795-826.

Baranger, M., \& Baranger, W. (2018). Die analytische Situation als dynamisches Feld. (deutsche Übersetzung von Baranger 1961/2). Psyche, 77(9), 734-738.

Bezoari, M., \& Ferro, A. (1982). Il sogno all'interno di una teoria del campo: aggregati funzionali e narrazioni. In E. Gaburri (a cura di, 1997), Emozione e interpretazione. Torino: Bollati Borlinghieri.

Bion, W. R. (1963). Gli elementi della psicoanalisi. Roma: Armando, 1973.

Blum, H. P. (2011). Sogni rivisitati. Rivista di Psicoanalisi, 2, 385-388.

Bolognini, S. (2008). Passaggi segreti. Torino: Bollati Borlinghieri.

Bolognini, S. (2016). Elementi di tecnica tra Sé e non-Sé. Rivista di Psicoanalisi, 62(1), 5-25.

De Toffoli C. (2014). Transiti corpo-mente. Milano: Franco Angeli.

Falci, A. (2005). Sulla definizione di fattori aspecifici nella terapia psicoanalitica. In G. Berti Ceroni (a cura di), Come cura la psicoanalisi (pp. 157-171). Milano: Franco Angeli.

Ferro, A. (2002). Fattori di malattia, fattori di guarigione. Genesi della sofferenza e cura psicoanalitica. Milano: Raffaello Cortina.

Ferro, A. (2003). Das bipersonale Feld. Konstruktivismus und Feldtheorie in der Kinderanalyse. Gießen: Psychosozial Verlag.

Ferro, A. (2005). Rèflexions à propos de l'interprètation. Bulletin de la FEP, 59, 44-46.

Ferro, A., \& Civitarese, G. (2015). Il campo analitico e le sue trasformazioni. Milano: Raffaello Cortina.

Galli, G. (1997). Beziehungen zwischen Lewins wissenschaftlichen Begriffen und der Psychoanalyse. Gestalt Theory, 19(2), 80-89. In Galli 2017, 107-115.

Galli, G. (2005). Psychologie der sozialen Tugenden. (2. Auflage). Wien: Böhlau.

Galli, G. (2017). Der Mensch als Mit-Mensch. Aufsätze zur Gestalttheorie in Forschung, Anwendung und Dialog. Mit Beiträgen von Anna Arfelli Galli und Giancarlo Trombini. Herausgegeben und eingeleitet von Gerhard Stemberger. Wien: Krammer.

Grotstein, J. S. (1983). Some perspectives of self-psychology. In A. Goldberg (ed.), The future of psychoanalysis. New York: International University Press.

Hochheimer, W. (1953). Die Rolle des Unbewussten im zwischenmenschlichen Verhalten. Psyche, 7(3), 161-184. In Hochheimer 1986, 215-240.

Hochheimer, W. (1954). Zur Analyse des therapeutischen Feldes. Psyche, 7(11), 648-675. In Hochheimer 1986, 241-272.

Hochheimer, W. (1986). Tiefenpsychologie und Kritische Anthropologie. Hrsg. von Reinhart Wolff, Band I. Basel/ Frankfurt: Stroemfeld/Roter Stern

Kästl, R. (2011). Zur Therapeutin-Klientin-Beziehung in der Gestalttheoretischen Psychotherapie. Phänomenal - Zeitschrift für Gestalttheoretische Psychotherapie, 3(2), 19-21.

Katz, S. M. (2017). Contemporary psychoanalytic field theory: stories, dreams, and metaphor. New York: Routledge.

Kellner, R. (1987). A symptom questionnaire. Journal of Clinical Psychiatric, 48, 268-273.

Lewin, K. (1926). Vorsatz, Wille und Bedürfnis. Berlin \& Heidelberg: Springer. 


\section{GESTALT THEORY, Vol. 41, No.3}

Lewin, K. (1946/1997). Verhalten und Entwicklung als eine Funktion der Gesamtsituation (1946). English version: behavior and development as a function of the total situation. In: D. Cartwright (ed.), Field theory in social science. Selected theoretical papers (pp. 262-278). Washington: A.P.A.

Mazzacane, F. (2013). Le vicissitudini del campo analitico. In A. Ferro (a cura di), Psicoanalisi oggi. Roma: Carocci Ed.

Metzger, W. (1962). Schöpferische Freiheit. 2. Auflage. Frankfurt: Waldemar Kramer.

Metzger, W. (1972). The phenomenal-perceptual field as a central steering mechanism. In J. R. Royce and W. W. Rozeboom (eds.), The psychology of knowing (pp. 241-265). New York/Paris/London: Gordon and Breach.

Metzger, W. (1982). Möglichkeiten der Verallgemeinerung des Prägnanzprinzips. Gestalt Theory, 4(1/2), 3-22.

Neri, C. (2007). La nozione allargata di campo in psicoanalisi. Rivista di Psicoanalisi, 53(1), 103-134.

Ogden, T. H. (2009). Rediscovering psychoanalysis. Thinking and dreaming, learning and forgetting. Hove, East Sussex: Routledge.

Panizza S. (2006). Per una psicoanalisi bipersonale. Milano: Franco Angeli.

Rausch, E. (1966). Das Eigenschaftsproblem in der Gestalttheorie der Wahrnehmung. In W. Metzger, \& H. Erke (eds.), Wahrnehmung und Bewusstsein. Handbuch der Psychologie 1,1 (S. 866-953). Göttingen: Hogrefe.

Rausch, E. (1982). Bild und Wahrnehmung - Psychologische Studien ausgehend von Graphiken Volker Bußmanns. Frankfurt/M: Waldemar Kramer.

Robutti, A. (1992). Incontro a un crocevia. In L. Nissim Momigliano, \& A. Robutti (a cura di), L'esperienza condivisa. Saggi sulla relazione psicoanalitica (pp. 11-19). Milano: Raffaello Cortina.

Sharpe, E. F. (1937). Dream analysis. London: The Hogart Press.

Solano, L. (2013). Tra mente e corpo. Nuova edizione. Milano: Raffaello Cortina.

Stemberger, G. (2009a). Feldprozesse in der Psychotherapie. Der Mehr-Felder-Ansatz im diagnostischen und therapeutischen Prozess. Phänomenal - Zeitschrift für Gestalttheoretische Psychotherapie, 1(1), 12-19.

Stemberger, G. (2009b). La molteplicità dell'Io e del suo ambiente. Il principio della molteplicità dei campi e le sue potenzialità nei processi diagnostici e terapeutici. In A. Zuczkowski, \& I. Bianchi (a cura di), L'analisi qualitativa dell'esperienza diretta. Festschrift in onore di Giuseppe Galli (pp. 275-282). Roma: Aracne.

Stemberger, G. (2018). Über die Fähigkeit, an zwei Orten gleichzeitig zu sein. Ein Mehr-Felder-Ansatz zum Verständnis menschlichen Erlebens. Gestalt Theory, 40(2), 117-131.

Tholey, P. (1998). Feldtheorien in Biologie, Biophysik, Psychologie und Sozialwissenschaften. Ein bisher unveröffentlichter Kommentar (1995) aus dem Nachlass von Paul Tholey. Mit einer Einleitung von Gerhard Stemberger. ÖAGP-Informationen, 7(5), iii-ix.

Tholey, P., \& Stemberger, G. (2009). Feldkonzepte, psychologische. Lexikon zur Gestalttheoretischen Psychotherapie. Phänomenal-Zeitschrift für Gestalttheoretische Psychotherapie, 1(1), 34.

Trombini, E., \& Trombini, G. (2006). Focal Play-Therapy in the extended child-parents context. A clinical case. Gestalt Theory, 28(4), 375-388.

Trombini, G. (1970). Das Selbermachenwollen des Kindes im Bereich der Ernährung und Entleerung. Praxis der Kinderpsychologie und Kinderpsychiatrie, 19(1), 1-10.

Trombini, G. (1994). Clinica psicologica e somatizzazione. In G. Trombini (a cura di), Introduzione alla clinica psicologica (pp. 76-102). Bologna: Zanichelli.

Trombini, G. (1995). Una promessa implicita nella terapia psicoanalitica: la relazione armonica con il paziente. In G. Galli (a cura di), Atti XV colloquio sull'interpretazione "Interpretazione e promessa" (pp. 127-135). Pisa: Giardini.

Trombini, G. (1998). Strutture pregnanti nella dinamica delle relazioni cliniche. In M. W. Battacchi, M. Bosinelli, P. E. Ricci-Bitti, \& G. Trombini (a cura di), Le ragioni della psicologia. Saggi in onore di Renzo Canestrari (pp. 301-308). Milano: Franco Angeli.

Trombini, G. (2014). Transferential relationships as field phenomena. The relationship dynamics in the light of the manifest dream. Gestalt Theory, 36(1), 43-68.

Trombini, G. (2015). La dinamica transferale alla luce del sogno manifesto e delle associazioni. Rivista di Psicoanalisi, 61(1), 45-64.

Turillazzi Manfredi, S. (1982). Due scopi per la psicoanalisi: verità e cambiamento. In G. Di Chiara (a cura di), Itinerari della psicoanalisi (pp. 250-278). Torino: Loescher.

Vallino, D., \& Macciò, M. (2004). Essere neonati. Roma: Borla. 
Giancarlo Trombini, born 1934, is an Emeritus Professor of Clinical Psychology and a Director of the Interdisciplinary Center for the Study of Psychosomatic Disorders at the University of Bologna. He is also a member of the International Psychoanalytic Association. In 1975, he was the Chair of General Psychology at the University of Padova, and in 1977, he was the first Italian Chair of Psychosomatic Medicine at the University of Bologna. He has been working for more than 30 years on psychosomatic disorders in adults and children, and he designed new psychotherapeutic methods for children (Focal Play-Therapy and Drawn Stories).

Address: Department of Psychology, Viale Berti Pichat, 5, 40127 Bologna, Italy.

E-mail: elena.trombini@unibo.it

Anna Corazza (born 1995, Bologna, Italy) graduated in Psychological Sciences and Techniques in 2017 with $110 / 110$ cum laude at the University of Bologna, with a thesis on ethnopsychiatry, a therapeutic proposal for immigrant people. She is currently studying a Masters in Clinical Psychology and Community at the University of Turin, and she is attending a year of Erasmus at the University of Seville (Spain), specializing in gender studies.

Address: Via Pilati 28, San Lazzaro di Savena (40068, BO), Italy.

E-mail: anna.corazza@edu.unito.it

Gerhard Stemberger (born 1947) lives in Vienna and Berlin. He is a psychotherapist and supervisor as well as a teaching therapist for Gestalt theoretical psychotherapy. His work focuses on the history and theory of the clinical application of Gestalt theory, in particular the theoretical foundation of Gestalt theoretical psychotherapy. He is the former president of the Society for Gestalt Theory and its Applications (GTA), long-time editor of the journal Gestalt Theory and co-publisher of Phänomenal-Zeitschrift für Gestalttheoretische Psychotherapie (Journal for Gestalt Theoretical Psychotherapy). He is also the editor and co-author of the books Psychische Störungen im Ich-Welt-Verhältnis (Mental Disorders in the I-World Relationship; 2002), Giuseppe Galli: Der Mensch als Mit-Mensch (Man as fellow-human; 2017) and Paul Tholey: Gestalttheorie von Sport, Klartraum und Bewusstsein (Gestalt theory of Sports, Lucid Dreaming and Consciousness; 2018).

Address: Wintergasse 75-77/7, 3002 Purkersdorf, Österreich.

E-mail: gst@gestalttheory.net 